\title{
WHATEVER HAPPENED TO RED CLYDESIDE?
}

\author{
INDUSTRIAL CONFLICT AND THE POLITICS OF \\ SKILL IN THE FIRST WORLD WAR*
}

SUMMARY: Recent studies of industrial conflict during the First World War have challenged earlier interpretations of working-class politics in Britain. The debate has focussed on the events in west Scotland during the years when the legend of "Red Clydeside" was made. It is now commonplace to emphasise the limited progress of revolutionary politics and the presence of a powerful craft sectionalism in the industrial workforce. This essay discusses the recent research on workplace unrest, popular politics and the wartime state. Although the "new revisionism" provides an important corrective to earlier scholarship, there remain important questions which require a serious reappraisal of the forces behind the different forms of collective action which took place and their implications for the politics of socialism. It is argued that the struggles of skilled workers made an important contribution to the growth of Labour politics on the Clyde.

\section{Introduction}

In the years following the outbreak of the First World War British politics were transformed. Before 1914 the Labour Party appeared as a pale shadow of European socialist parties, forming a radical wing of the Liberals with few prospects of independent power. ${ }^{1}$ Within a decade Labour had assumed office with the support of a small Liberal Party. This change in the fortunes of the parties was most vividly illustrated in the west of Scotland, where the urban centres were swept by Labour victories in the early $1920 \mathrm{~s}$, giving Scotland a distinctive political identity that has remained intact to the present day. ${ }^{2}$ At the centre of the debate of the making of class politics in modern Scotland stands the industrial conurbation of "Red Clydeside". Many of the brilliant socialists who led the celebrated campaigns of the decade 1914-1924 were born or educated in the city and it was their activities and writings which secured Glasgow's reputation as the political

* My grateful thanks to Keith Burgess, John Foster, James Hinton, Iain Hutchison, Alan McKinlay, Jeff Porter and the referees of this journal for their helpful comments on this essay.

${ }^{1}$ See R. McKibbin, The Evolution of the Labour Party (Oxford, 1974), for an influential interpretation.

${ }^{2}$ D. Howell, A Lost Left: Three Studies in Socialism and Nationalism (Manchester, 1986), pp. 10-13, 281-285. 
capital of socialist Scotland, creating a legend of heroic class struggle which became part of the country's political discourse.

The rise of socialist politics throughout Europe has recently been attributed to three major forces: the spread of industrialisation and the growth of an urban workforce; policies pursued by European states; and the strategies pursued by the socialist parties themselves. ${ }^{3}$ Studies of British socialism have focussed on similar themes. The struggles of workers against changes in production, the cultural resources of the working class, and the responses of the different socialist parties to the British state have all figured in recent accounts. ${ }^{4}$ Marxist scholars have usually explained the changing politics of these years in terms of class conflicts provoked by changes in the structure of production. Enormous attention has been paid to the workings of small socialist and syndicalist parties, seen as a prelude to the foundation of the Communist Party in 1920. By comparison the evolution of Labour politics has often been dismissed by radical historians as a vehicle for conservative institutions and interests within the union movement. ${ }^{5}$ This research gap has been filled by liberal historians, critical of marxist accounts such as William Gallacher's celebrated Revolt on the Clyde. ${ }^{6}$ The general concern of Liberal historians has been to emphasise the impact of institutional change rather than the force of direct action in the making of socialist politics. The growth of mainstream Labour politics is presented in terms of campaigns on electoral issues such as housing or the struggle for economic reform, rather than conflicts on the shop floor of industry. This approach has been influential in recent years in persuading historians to reappraise the role of consumers' campaigns (such as those for better housing) in attracting support for Labour in different parts of Britain. $^{7}$

${ }^{3}$ D. Geary (ed.), Labour and Socialist Movements in Europe before 1914 (Oxford, 1989), pp. 4-6, 118-131 and passim.

${ }^{4}$ J. Holford, Reshaping Labour: Organisation, Work and Politics (London, 1988), and M. Savage, The Dynamics of Working-Class Politics (Cambridge, 1987), for two recent accounts.

5 J. Saville, "The Ideology of Labourism", in R. Benewick et al. (eds), Knowledge and Belief in Politics (London, 1973), for an influential account of "labourism", reworked in B. Schwarz and M. Durham, "'A Safe and Sane Labourism': Socialism and the State 1910-24", in M. Langan and B. Schwarz (eds), Crises in the British State 1880-1930 (London, 1985), pp. 126-150.

${ }^{6}$ W. Gallacher, Revolt on the Clyde (London, 1936), reprinted in 1978, and Last Memoirs (London, 1966). More recent Marxist accounts include W. Kendall, The Revolutionary Movement in Britain, 1900-1921 (London, 1969), and R. Challinor, The Origins of British Bolshevism (London, 1977).

${ }^{7}$ H. Pelling, The Origins of the Labour Party, 1880-1900 (Oxford, 1965), p. 218 and passim; R. McKibbin, "Why was There no Marxism in Great Britain?", English Historical Review, XCIX (1984), pp. 295-331, for liberal accounts. See Savage, The Dynamics 
These studies have illuminated the diversity of popular politics and the complex sources of socialist politics. There still remains the problem of the unions' massive presence within the Labour Party and the peculiar contribution of skilled workers to both union and Labour politics. The craft societies are often described as the privileged enclosure of sectional trades, concerned to defend their exclusive, masculine world against women and the lesser skilled. The scope for radical or socialist politics appears to have been restricted by the sectional boundaries of unionism and their anxiety to defend occupational interests. The evidence of craft sectionalism raises the larger question why such areas as west Scotland, with its large congregations of skilled workers, should occupy such a prominent position in the advance of socialist politics in Britain. Amongst the brilliant generation of "Red Clydesiders" were a number of skilled tradesmen who believed their working lives provided a political apprenticeship for socialism.

The role of skilled workers in the making of Scottish socialism remains a subject of intense debate. For the heroic years of "Red Clydeside" encompass the rapid changes seen in the structure of trade unionism and the constitution of the Labour Party, as well as numerous campaigns to influence the British government. The following section reviews some of the recent research on Clydeside politics, including the role of skilled workers in wartime conflicts. These accounts give valuable insights into the diversity of political views and campaigns during the war years, but they also obscure some of the critical connexions between workplace struggles and political commitment. An alternative view of industrial unrest is outlined in an examination of workplace conflicts during the war. To assess the political significance of these struggles, it is argued here, we also need to consider the contribution of non-work campaigns to the growth of socialist politics.

\section{Debates on Red Clydeside}

On the outbreak of war, Clydeside was simply an important industrial conurbation. The Liberals had dominated the electoral politics of central Scotland for generations and had little reason to anticipate serious unrest as it moved to mobilise for mass warfare. This strength of Liberalism may help to explain the disastrous complacency of the Government at different periods of the war, which culminated in the near-panic of Lloyd George at the discovery of serious unrest in Glasgow during the "Forty Hours Strike" in 1919. It was these dramatic conflicts between the state and Scottish workers that were assembled into a narrative of heroic struggle by the first

of Working-Class Politics, and J. Smith, "Labour Tradition in Glasgow and Liverpool", History Workshop Journal, 17 (1984), pp. 32-56, for changing perspective of Marxist scholars. 
generation of "Red Clydesiders". It is also the rebellion of industrial workers that has attracted the most attention from historians of the period. One of the most powerful accounts of these conflicts is that of James Hinton, who provides a general analysis of workplace militancy and tradeunion politics as well as a detailed discussion of wartime conflicts on the Clyde. ${ }^{8}$

Hinton argued that the backbone of industrial militancy was formed amongst the engineering craftsmen threatened by new technologies and provoked into open resistance during the Government's dilution programme. The most familiar response of these labour aristocrats was to defend their craft privileges, but a significant section of the workforce recognised the need for fresh strategies. These rank-and-file radicals were led by a group of brilliant shop stewards opposed to the policies of moderate officials and ready to confront aggressive employers or government bureaucrats. Influenced by the Socialist Labour Party and similar bodies, this group created the Clyde Workers' Committee (CWC) to coordinate resistance and formulate a radical policy of dilution which would secure workers' control. During the winter of 1915-1916, the socialist stewards challenged the authority of the British state until they were weakened by internal frictions and finally crushed by a sinister alliance of employers, civil servants and politicians.

In developing these arguments, Hinton outlines a model of workplace militancy and institutional repression which explains the revolt of the skilled engineers and documents the continuities between syndicalism and early Communist politics. He stresses the role of industrial and occupational structures in shaping the political values of craftsmen. Shop-floor militancy was more developed in engineering trades where the impact of technical change was greatest, and was most intense in those firms which had pioneered management reform. The structure of Glasgow's engineering industry, with its general manufacturing output, helps to explain the peculiar geography of workplace unrest. The growth of munitions production led to a rapid increase of both union membership and shop-floor militancy, whilst specialist marine engineering saw much less unrest. Hinton also argues that the Clydeside unrest followed a distinct chronology in 1915-1916. The engineers led the February 1915 wages strike but dropped out of sight until the autumn, in the aftermath of the bitter struggle over the Munitions Act. It was in the campaign against the dilution of engineering that the famous Clyde Workers' Committee (reborn in the autumn of 1915) made its impact. The summer campaigns against the Munitions legislation were almost all restricted to the shipyards, which also suffered from the

8 J. Hinton, The First Shop Stewards' Movement (London, 1973), pp. 29-41, 115-129, 143-152 and passim. 
worst rent rises of the time. Hinton is convinced that these campaigns did not converge with the activities of the Clyde Workers' Committee. It was the dilution of munitions output which brought the class-conscious shop stewards into direct confrontation with the British state.

This interpretation of wartime conflict has been challenged in Iain McLean's Legend of Red Clydeside, which suggests that our understanding of Scottish society and politics has been badly distorted by the various mythologies of class struggle on the Clyde. McLean rejects Hinton's portrait of wartime conflict and concludes that the cadres of the Clyde Workers' Committee were isolated and confused in their dealings with a progressive government. Their own union officials were attacked for betraying their members but were, in fact, striving to manage the narrow conservativism of their members. The legacy of shop-floor unrest during the war years was not progressive politics but destructive sectionalism which inhibited the growth of the Labour Party. It was Labour's remarkable success in dealing with the housing question and religious sectarianism that enabled the Party to overcome the industrial squabbles of 1914-1919 and build a wide constituency of support in Glasgow. ${ }^{9}$ Whereas Hinton depicts the Ministry of Munitions as the longest arm of a Servile State, intent on subordinating a restive labour movement to the political control of capitalism, McLean sees the Government departments as dominated by progressive politicians and experienced civil servants - driven into repressive actions during crises but generally seeking the cooperation of organised labour. ${ }^{10}$

McLean's account suggests that the marxist shop stewards were marginal to mainstream political developments, yet he largely endorses the analysis of shop-floor change outlined by Hinton. McLean accepts the polarisation of workers' attitudes around the principles of "craft conservatism" and "rank-and-file militant", though he argues that conservative views were massively predominant amongst skilled workers. The structural divide between engineering and shipbuilding is another feature of McLean's work, though he tends to disregard the impact of industrial developments in the making of popular politics after the war. Labour support is traced to the urban questions of housing and religion, rather than to class struggle on the shop floor of industry, and McLean draws out the discontinuities between wartime unrest and post-war electoral success. McLean's work shows a much firmer grasp of complex voting patterns than industrial innovations.

Further contributions to the revisionist interpretation of Clydeside politics have been provided by Alastair Reid and Gerry Rubin. ${ }^{11}$ Reid argues

${ }^{9}$ I. McLean, The Legend of Red Clydeside (Edinburgh, 1983), pp. 154-173.

${ }^{10}$ Ibid., pp. 81-85 and passim.

11 A. Reid, "Dilution, Trade Unionism and the State", in S. Tolliday and J. Zeitlin (eds), Shop Floor Bargaining and the State (Cambridge, 1985), pp. 46-74, and "Glasgow Socialism", Social History, XII (1986), pp. 89-97, and G. Rubin, War, Law and Labour 
that Hinton has seriously exaggerated the importance of the dilution campaign in the struggles of the war years, and also misunderstood its political importance. Reid also argues that the most serious phase of wartime unrest actually involved the resistance of shipyard workers to the Munitions Act of 1915, which was reinforced by the campaign against rent rises in the shipyard districts. ${ }^{12}$ The dilution campaign, in contrast, was confined to the engineering trades and did not affect the great shipyards of the Clyde. Whereas the engineering shop stewards fought their officials, the example of shipbuilding demonstrates the harmony of views between officials and rank-and-file workers over conservative policies towards dilution - which proved extremely effective in the shipyards. ${ }^{13}$ Reid differs from McLean in emphasising the importance of wartime industrial policies in advancing popular politics, though he suggests that it was the positive experience of Government control rather than the repellent features of a "Servile State" that advanced the cause of Labour socialism and increased support for collectivist policies after the War. ${ }^{14}$

This view is supported in some respects by the findings of Gerry Rubin, whose work on the Glasgow Munitions Tribunal concludes with the argument that union officials were converted to the cause of state regulation by the experience of legal regulation under the munitions courts. Rubin presents these tribunals as the agents of a state that was evolving a corporatist structure to deal with the pressures of manpower planning during the war. This complex process was not organised by the businessmen imported by Lloyd George but by a bureaucratic elite that sought to secure a balance between the interests of capital and labour in a bargaining process that included legal sanctions. Rubin shares with Reid the conviction that their experience of wartime planning converted a substantial part of the labour movement to a moderate socialist reconstruction which complemented the evolution of Labour Party politics. ${ }^{15}$

The debates on wartime struggles have focussed attention on two issues: the attitudes of craftsmen to innovation and to their own societies; and the policies pursued by the British state towards the labour force. Different writers agree on the strength of "craft conservatism" amongst the skilled workforce, though recent revisionist writers (such as McLean and Reid) argue that this defensive policy served the unions well during the war since the government was prepared to make large concessions to organised workers in return for cooperation. The actions of the benevolent state were

(Oxford, 1987).

${ }_{12}$ Reid, "Dilution, Trade Unionism and the State", pp. 49-51.

13 lbid., pp. 65-67 and passim.

${ }^{14} \mathrm{Ibid}$, p. 65 for argument that the Government was pro-labour from the start.

${ }^{15}$ Rubin, War, Law and Labour, pp. 14-19, 140, 204-209; see J. Melling, "The Servile Revisited", Scottish Labour History Society Journal (1989), for a response to Rubin. 
even more important in matters such as housing and rent controls, and it was the experience of wartime collectivism which provided the Labour Party with a working model of socialism. Whereas marxist historians had seen the demands of the Clyde Workers' Committee as the blueprint for workers' control and the high point of class struggle, the revisionists argue that these were irrelevant to the concerns of Clyde tradesmen. The road to socialism lay through the campaigns outside industry and the positive reforms of the liberal state. Both the marxist and revisionist writers tend to see sectionalism as the natural politics of the craftsmen, with skilled workers defending their property rights over the trade against innovations and other workers. Hinton argues for the disruption of such traditional craft views by a minority of militant rank-and-file workers, whilst McLean and Reid dismiss the significance and strategies of such groups.

It is arguable that the existing literature provides only a partial, if valuable, insight into the origins and impact of wartime conflicts on the Clyde. The categories of "shop-floor militant" and "craft conservative", used to indicate a clear polarisation of workers' attitudes, only serve to obscure the range of trade strategies and occupational values expressed by the workforce. The divergent experience of the engineering and shipyard trades demonstrates that there was no single pattern of workplace struggle or union policy-making on the Clyde. Much of the composition of skill itself lay in the physical conditions of the workplace. Crafts were constructed not simply in response to the logic of the production process, but out of the specific innovations of craftsmen or labourers within a peculiar environment. The expression of fraternity or sectionalism was always made in relation to specific conditions and institutions, rather than flowing simply from the existence of skill. These expressions and institutions of craftsmanship were necessarily structured by the existence of capitalist authority relations and the rule of law. It is from these specific circumstances that the skilled workers receive their impressions of power and privileges.

To understand the power of skill in pre-war Glasgow we need to recognise the importance of physical conditions and practical struggles in the defence of craftsmanship. The institutions of the craft were in transition across the Clyde basin, as employers sought to tighten their control of production and devise procedures of bargaining. Beneath the diversity of craft practices lay the authority of the employer and his determination to ensure that local custom did not degenerate into irresponsible autonomy. In this sense the politics of the trades only make sense when they are related to the power of the employer and the wage relationship. Struggles for control of the labour market and craft sectionalism have to be seen in this light. It was the arrival of war and government controls which disturbed the delicate balance of forces which had dictated the pattern of bargaining for generations. Officials, shop stewards and groups of craftsmen now sought 
to manoeuvre for position in a situation where the labour market was directly regulated. The implicit power relations which were embodied in the division of labour and the procedure of the bargaining institutions were openly politicised as the state sought to control production. This control had to be adapted to the peculiar conditions of each industry, and variations in work experience and union policies can still be found after 1914, but the common feature of wartime conflicts was their challenge to authority. The challenge was usually implicit, turning on such questions as supervisory power, but the controversy over the Munitions Act forced industrial workers to reappraise their assumptions about government itself. The second vital feature of wartime unrest on the Clyde was the convergence of industrial and non-industrial campaigns which gave rise to a distinctive form of politics in west Scotland. Earlier studies argue for the separate chronology of struggles over wages, Munitions Act, dilution, high rents and military conscription. Yet it was precisely the integration, at strategic moments, of workplace and non-work struggles which marks a critical advance for socialist politics in west Scotland. These campaigns were joined by the common purpose of resisting the "profiteering" of property-owners and the repressive actions of the British state. The extraordinary demand for labour and the rupture of authority relations in industry radically altered the role of the unions. As they were drawn into the new procedures for conciliation, designed by the state, their capacity for fighting the employers changed also. It was in this context that the key conflicts over the Munitions Act and the dilution of labour took place.

\section{The struggle against the Munitions Act}

Engineering workers on the Clyde first attracted national attention when they struck work in February 1915 after the employers refused to seriously consider their demand for a wage rise of $2 \mathrm{~d}$ per hour. That dispute forced the Government to recognise the vital role which ironworkers would play in the supply of munitions to the armed forces. Following the strike the Treasury, under Lloyd George, reached an agreement with the major unions on the manufacture of shells and fuses. In June-July 1915 the state confirmed its interest in the armaments trades by passing the Munitions legislation, including a notorious clause which gave employers in "controlled establishments" the power to issue or refuse certificates of discharge for their workmen. The controversy over "leaving certificates" assumed crisis proportions in the autumn of 1915 , as Clydeside tradesmen were prosecuted, fined and imprisoned after complaints of employers to Munitions Tribunals. The Ministry of Munitions was bewildered and dismayed by the furore over the legislation, which threatened to destroy the prospects 
for a dilution of skilled labour. An enquiry was appointed to investigation the whole problem of Clyde unrest.

There is general agreement in the literature that the resistance to the Munitions Act of 1915 originated in the Clyde shipyards. The official enquiry into the unrest on the Clyde concluded that the revolt amongst the shipyard trades could be traced to the clumsy actions of particular firms, such as the notorious Fairfield Shipbuilding and Engineering Company of Govan. ${ }^{16}$ This does not explain why the shipyards as a whole should have mobilised against the legislation in the autumn of 1915 . The engineering trades were, in fact, affected by the measure and the engine departments of shipyards saw conflicts similar to those recorded in the building areas. ${ }^{17}$ Even machinists complained of the legislation and its adverse effect on their work and earnings. ${ }^{18}$ Many engineering workers felt deeply threatened by the legislation, including the celebrities of the Clyde Workers' Committee (as we shall see). Yet it remains true that some of the most bitter and protracted disputes involved such trades as coppersmiths, shipwrights and caulkers.

The explanation for the prominence of shipbuilding workers in the cases brought before the Munitions Tribunals can be found in the distinctive forms of work organisation and bargaining developed before the war. Shipbuilding workers had devised skills that were adapted to the physical constraints of vessel construction. Strategic trades such as the hull platers needed to be well prepared and highly mobile in their activities, arranging for groups to undertake specific jobs in accordance with the changing needs of the yard. This craft administration of work and piecework payments was regulated by the hierarchy of supervision and management, but the practical distribution of work was characterised by on-job discretion which may be termed "primitive autonomy". As an official of the powerful Boilermakers' Society explained: ${ }^{19}$

It is the custom of the shipbuilding industry for men to form their own squad, their own mates, and never in my whole experience do I remember of an employer interfering with the arrangement of $[\ldots]$ a squad of platers $[\ldots]$

${ }^{16}$ Ministry of Munitions, Clyde Munition Workers. Report of Lord Balfour of Burleigh and Lyden Macassey (1915) Cd. 8136, paragraph 2 [hereafter, "Balfour-Macassey Report"].

${ }_{17}$ Ministry of Munitions [MUN] records, Public Record Office, Clyde Munition Workers. Minutes of Evidence of Official Enquiry, MUN 5 80/341/3, pp. 292, 432-439ff. [hereafter, "Balfour-Macassey Enquiry Minutes"].

${ }_{18}$ Ibid., pp. 427-430, for Duthie of United Machine Workers at the Albion plant.

19 Ibid., p. 9, William Sharp of the Boilermakers' Society. 
This kind of autonomy was always limited by the presence of trade foremen but the physical constraints on the supervision of such a dispersed production process left the tradesmen with a large margin of freedom. Even piecework rates could be negotiated on a face to face basis. Constant movement between a group of yards was another important feature of the industry which enabled workers to express their personal preferences as well as bidding up the price of their labour.

Before 1914 the employers found it extremely difficult to secure the cooperation and flexibility of the workforce in conditions of primitive autonomy and sought a measure of institutional control through the union in return for a recognised procedure. Union officials exploited the disorders of the labour force as a means of extracting concessions from the shipbuilders. ${ }^{20}$ Proceduralism did not remove primitive autonomy since it derived strength from those very conditions. Nor did official union arbitration outlaw the demarcation disputes in the industry. In the face of changing vessel types and technologies, competing trades battled to retain their customary control over areas of work and resisted the interference of management. ${ }^{21}$

This complex world of precedents and personal relations was held in tension before 1914 by the strong demand for British ships and the agreements reached with the Boilermakers' Society. Skilled workers also dominated the engineering trades in the 19th century but had been defeated by their employers in the great lockout of 1897-1898, which imposed the Terms of Settlement on the craftsmen. The employers' victory allowed the most progressive firms to reform their shops, introduce new machinery and secure greater technical control of work before 1914, despite the rearguard action of the unions. ${ }^{22}$ Engineering tradesmen continued to control the more complex jobs but they could not stem the growing employment of semi-skilled grades and 'handymen' on routine machine jobs.

In the face of varied customs and changing practices across the different engineering districts, the Amalgamated Society of Engineers (ASE) had to reassess its policies after 1898 . Their attempt to control the new machines had failed and the union fell back on the arguments that tradesmen should be given preference on machines and that the integrity of skilled work should not be damaged by the separation of repetition work from specialist tasks. If this happened then the craftsmen still had the right to consider the rough, basic tasks as their domain. This policy of "following the job" was

${ }^{20}$ Ibid., pp. 510-513, for Lawson and Lorimer's comments.

${ }^{21}$ J. Melling, " 'Non-Commissioned Officers': British Employers and Their Supervisory Workers, 1880-1920", Social History, V (1980); K. McClelland and A. Reid, "Shipbuilding workers", in R. Harrison and J. Zeitlin (eds), Divisions of Labour.

${ }^{22}$ This view can be contrasted with that of J. Zeitlin, "Engineering workers", in H. Gospel and C. Littler (eds), Management Strategies (Heinemann, 1982). 
complemented by the defence of skilled wages: whether engaged on rough scraping or fine cutting, they insisted on a payment of the trade rate for the job. Such claims could only be effective if the unions could be sure of their hold over the labour market. The ASE and other societies decided on a sustained membership drive before 1914, including attacks by the Amalgamated on the smaller "sectional" societies within the industry. ${ }^{23}$ It was essential for such bodies as the ASE to complement its involvement in centralised procedures with local contacts. There were not only District Delegates and Secretaries (such as Brodie and Bunton on the Clyde) but the officers of the District Committees and "unofficial" shop stewards. To organise their membership drives the Clyde tradesmen also formed semiautonomous "vigilance committees" of officers and stewards, who pressed for union recognition and total membership in local firms. ${ }^{24}$ Relying on union discipline to provide unity in the trade also had its difficulties, as the ASE Executive discovered when it faced rebellions in the various districts before 1914. ${ }^{25}$

The outbreak of war disrupted the precarious balance of forces in engineering as well as shipbuilding, with the unprecedented demand for skilled labour throughout the Clyde district. A major dispute over wages swept the engineering trades in February 1915, whilst the rising prices and rents of these months encouraged workers to take advantage of labour shortages in direct bargaining for better wages, overtime and "war bonuses". Shipyards as well as engineering and armaments works hoarded skilled workers and poached those of their competitors as government contracts became available to local firms. The normal discipline of the labour market drained away as foremen found themselves pressed to fulfil contracts and retain workers at all costs.

It was precisely these difficulties that the Munitions Act of 1915 was designed to resolve. The most acute shortages were in the supply of shells, fuses and small arms, though it was clear from the earliest days of the Munitions Ministry that the state would control the shipyards as an essential arm of munitions production. ${ }^{26}$ The Government defined "munitions" in the broadest terms and insisted on the supremacy of the state's interests in dealing with the organisation of output. ${ }^{27}$ In drafting the measure, Lloyd

${ }^{23}$ Melling, "Non-Commissioned Officers".

${ }^{24}$ Labour Party, Report of the Special Committee appointed to inquire into the [...] Deportations of [. . ] Workmen employed in Munitions Factories in the Clyde District (London, October 1917), p. 12 (hereafter, Labour Party Report].

${ }^{25}$ B. Weekes, "Primitive Democracy ...", (Warwick, 1980), manuscript draft for a general discussion on internal democracy in the ASE.

${ }_{26}$ W.J. Larke, "Notes on Controlled Establishments", 25.8.1917, in MUN 5 353/360/4, pp. 1-2.

${ }^{27}$ J. Melling, Rent Strikes (Edinburgh, 1983) for a discussion of the prosecution of "munitions workers" from both shipyards and engine shops in the rents struggle of 1915. 
George had consulted the union leaders and agreed to tax excessive profits as well as restore the trade practices after the war ${ }^{28}$ The Minister believed he had removed the fear of the skilled workers that their employers would use munitions manufacture as a means of breaking craft controls and introducing a new division of labour in heavy industry.

The violent reaction in Clydeside and other districts to the Munitions Act took both the Government and the union officials by surprise. The Munitions Act prevented the skilled workforce from using its extraordinary bargaining power at a time of labour scarcity and rising prices, but it actually strengthened the hand of the employers by introducing the hated leaving certificates which had to be issued before workers could change their job. This section of the Act armed the supervisors and managers with an unprecedented legal instrument to restrict the free movement of employees and radically altered the balance of power in the workplace. Before the war workmen had been able to calculate the limits of direct bargaining by their knowledge of customs and personal negotiations with the foreman. The dissatisfaction of the men and the authority of the supervisor could be expressed with brutal frankness. With the unusual conditions of wartime demand and the introduction of the Munitions Act the situation was transformed. The recognised customs of the shipyard were superseded by shop rules placed on a quasi-legal basis. In a situation where the exercise of authority itself was the issue, it became inevitable that the "lawful orders of the foreman" would be the test of the new policies. A particularly acrimonious dispute at the Dalmuir Shipyard of Beardmores broke out when a foreman caulker brusquely broke up a lunchtime gathering of his tradesmen called to discuss the piecework rates offered for submarine work. ${ }^{29}$ During the prosecution of workers for disobeying their foreman the whole subject of customary practices and the "unwritten law" of the shipyard was exposed to fierce debate as the tradesmen sought to defend their traditional autonomy from management control and the Munitions Tribunals. ${ }^{30}$

Similar arguments arose when a shipbuilder attempted to transfer rivetters from repair to new construction work under an unpopular foreman. In this instance the employer did not even challenge the principle that workers could take their "place of employment" as the point where they were hired by a foreman but disputed the facts of the case. ${ }^{31}$ The high turnover of squads and the ready movement of workers around the shipbuilding yards made the "clearance certificates" deeply unpopular as the firms tried to tie down workers, even when their order book did not justify

${ }^{28}$ Larke, "Notes on Controlled Establishments", MUN 5 353/360/4.

${ }^{29}$ Balfour-Macassey Enquiry Minutes, pp. 97-107 and passim.

${ }^{30}$ Ibid., pp. 128-132, 139.

${ }^{31}$ Ibid., pp. 18-24, 41-46, 50, for Elderslie Dock case. 
their retention. Complaints against individual foremen and the view of Balfour and Macassey (in the official Report on the unrest), that the policies of particular firms had provoked the revolt of the Clyde, missed the fundamental point. ${ }^{32}$ The Munitions Act altered the whole basis of direct bargaining and threatened the autonomy of the workforce. Union officials had hoped that the machinery of the Act would strengthen proceduralism in the industry and allow them to bargain directly with the Government. They badly underestimated the employers and by autumn 1915 a major crisis faced the industry when the Govan shipwrights were imprisoned by the Munitions Tribunal.

Although the shipyards were particularly prone to friction over the interpretation of yard rules and the discretion of the foreman, a number of engineering works were involved in Tribunal cases under the Act. Critics of the over-mighty foreman included the officials of the United Machine Workers' Society who told the official Enquiry in November 1915 that the extraordinary power of supervisors was a "very great grievance of the workers in the Clyde area". ${ }^{33}$ Complaints over the enticement of tradesmen by promises of overtime and the unreasonable refusal of clearance certificates to deserving cases were brought by ASE officials as well as the shipyard trades. In the engineering shops there was usually greater continuity of work and less scope for the renegotiation of rates once the pay increase of March 1915 had been awarded by the Committee on Production.

The geography of the Clyde area, with a concentration of shipbuilding, marine engineering and armaments production in such well-defined burghs as Govan and Clydebank-Dalmuir actually served to break down the barriers between the skilled workers in these areas. Here the trades councils played a critical coordinating role and rallied support across the crafts. ASE activists such as Harry Hopkins and J. S. Taylor united the Govan Trades Council unions in opposition to the Act and a demand for the release of the shipwrights. ${ }^{34}$ The campaign provided the conditions for the rebirth of the Clyde Workers' Committee as well as activating the skilled workforce in what Macassey described as a "corroding suspicion of every clause" of the Munitions Act. ${ }^{35}$ This impression was confirmed by Lloyd George himself

${ }^{32}$ Balfour-Macassey Report, p. 4 paragraph 8 for comment on foremen.

${ }^{33}$ Balfour-Macassey Enquiry Minutes, p. 291.

34 The Glasgow Labour paper, Forward, which was to be suppressed in early 1916 for its seditious reporting, praised the local union officials as well as "the rank and file" and the Govan Trades Council (6-11-1915). It revealed that one of the gaoled shipwrights was an active member of the ILP and a Superintendant of the Socialist Sunday School. Such extracts were collected by the Ministry in MUN 5 70/324/18.

${ }^{35}$ Lynden Macassey Memorandum, "Munitions of War: Certain causes of Unrest among Munition Workers on Clyde and Tyne-side. . .", 18-12-1915, p. 3, in the "Materials supplied to Mr Lloyd George before his visit to the Clyde and Tyne", MUN 5 
when he arrived at the great Parkhead engineering works during Christmas 1915 and was introduced as the architect of the "Slavery Act" which was hated throughout the district. ${ }^{36}$

Such evidence suggests that an exclusive emphasis on the resistance of the shipyards to the Munitions Act can obscure its significance for the engineering trades and the growing unrest over the dilution of labour. The efforts of earlier writers to demonstrate the separate origins of the antiMunitions and the dilution struggles obscures the fact that the Clyde trades shared a common concern to restrict the powers of the employers under the Act, which defined shipyard as well as engineering labour as controlled under the Munitions Act. At the centre of the campaign was the question of legitimate authority. The attempt of the Clyde firms to use legal sanctions against their workers had thrown the whole system of Munitions Tribunals into crisis. The Government had to take account of this in framing its dilution programme during the winter of 1915-1916. Even if dilution would affect the trades differently, the same issues of authority and discipline were to surface in the conflicts of early 1916.

\section{The dilution struggle on the Clyde}

The purpose of the Government's dilution policy was to import into industry untrained male and female workers, enabling the munitions firms to upgrade skilled and semi-skilled workers. This general principle was established as early as spring 1915, but the remaining months of that year were spent in efforts to put this principle into practice. In his detailed study of Clydeside dilution, James Hinton suggested that the opposition to official policy came from two distinct groups of engineering workers: the "craft conservatives", who expressed traditional values in their opposition to dilution, and the "radical rank-and-file" workers led by the socialist shop stewards of the Clyde Workers' Committee. Trade-union officials are portrayed as both craft conservatives and bureaucratic officers committed to fixed agreements with the employers. After the disastrous experience of the Munitions Act, negotiated by their own officials, local tradesmen were deeply suspicious of such agreements. This was the context for the open friction within unions such as the ASE during the critical months of 19151916. To elaborate these arguments, Hinton compared the experience of craft conservatism found in the Johnstone works of Langs, with the progressive stand taken by such stewards as Gallacher and Muir. The erratic

73/324/15/2. A manuscript version exists in MUN 5/72/324/15/1; Labour Party Report, p. 13.

${ }^{36}$ D. Kirkwood, My Life of Revolt (London, 1935), pp. 96-97, 107-110 for Kirkwood's colourful account, including his denunciation of the Act for "branding" Beardmore workers with a capital B. 
behaviour of David Kirkwood at the great Parkhead works is taken, in part, to exemplify the tensions between the traditional arrogance of the craftsman and the radical aspirations of the Clyde Workers' Committee. ${ }^{37}$

The difficulty with Hinton's plausible account is the suggestion that we can clearly distinguish between the values of traditional craftsmen and the goals of political activists. In this view the Lang craftsmen were engaged in a narrow defence of their privileges and wages, whilst the radical shop stewards were devising political strategies to secure workers' control of dilution. Similarly, Hinton suggests that there was a fundamental difference between the policies advocated by the shop stewards and the collaborative strategies of union leaders. ${ }^{38}$ The defeat of the CWC marked the end of the political challenge to the authority of capitalism on the shop floor of industry. Such an interpretation captures only part of the dilution story. It underestimates the complexity of both craft opinion on the Clyde and the internal politics of the unions. A review of the evidence indicates that the shop stewards as well as the union officials were seeking to defend the prerogatives of the trade. The leading Clyde stewards used their unofficial authority to devise a means of controlling dilution, having lost confidence in their national officers. Their successes were overshadowed by the crisis of March 1916, which arose out of a specific, if significant, agreement reached at Parkhead. This crisis also revealed the real nature of the challenge posed by the Clydeside engineers to the prerogatives of capitalism.

The first signs of serious trouble over dilution came at the Lang works in the late summer of 1915 when the three Lang brothers notified the unions that both male and female dilutees would be introduced at Johnstone (some distance from Glasgow). As one of the most aggressive reformers in west Scotland, Langs had faced similar problems to those at Weirs and Rowans (which whom they had personal connexions) before 1914. ${ }^{39}$ ASE officials hurried from Glasgow to protect their members' rights over the turning, grinding and fitting operations in the manufacture of machine tools at the plant. Local stewards were determined that the firm should not exploit the situation to substitute cheap female labour for time-served men and matters came to a head in early December when nine women and one forewoman were taken on at the works. ${ }^{40}$ Under pressure from the unions the Ministry of Munitions pressed Langs to scale down their dilution programme, pro-

${ }^{37}$ Melling, Rent Strikes, for details.

${ }^{38}$ Hinton, First Shop Steward's Movement, pp. 149-151 for Kirkwood; cf. Kirkwood, My Life of Revolt, pp. 60-63 for his self portrait as a journeyman.

${ }^{39} \mathrm{~J}$. Paterson, Memorandum on the progress of dilution, 18-12-1915, MUN 5 73/324/ $15 / 2$, pp. 2-3 for discussion of Langs and the view of Rowan Thomson; W. Weir, "Criticism of the methods of Dilution: Notes for Mr. Lloyd George", December 1915, MUN 5 73/324/15/4, gives Weir's forceful views on Langs and other matters.

40 Paterson Memorandum, pp. 5-8. 
voking fierce criticism from local industrialists and the Ministry's own representative in Glasgow. ${ }^{41}$

The Lang dispute did provide an exhibition of defensive craftism, but this has to be seen in the context of struggles with local employers and of complex union growth in the Paisley-Johnstone area. The ASE's main anxiety was that the employers would use dilution to pioneer a new division of labour, with rough tasks given to untrained machine workers and craftsmen left to set the machines and finish the job. To avoid the dilutees becoming a permanent source of cheap labour the ASE argued that all work previously undertaken by tradesmen (whether highly skilled or not) should be seen as the province of the craftsmen and must be paid at the full rate. The Circulars of the Central Labour Committee provided for the payment of trade work at the standard rate, whilst the ASE's own executive argued that Local Advisory Committees should administer the progress of dilution and ensure the payment of these rates. ${ }^{42}$ The Lang case gave the ASE the classical example of a firm which was not directly engaged in the production of munitions - rather the manufacture of machines that tooled the whole engineering industry - but where wartime reforms could have a dramatic impact on industrial skill. The workers' response was complicated by the existence of inter-union rivalries at Johnstone which further exposed the vulnerable position of the ASE. An important section of the workforce belonged to the Amalgamated Toolmakers' Union, which the ASE variously described as a band of "unrecognised men" and the source of workshop resistance at Langs. ${ }^{43}$ It seems more likely that this smaller body was a breakaway from the ASE and competed with it by emphasising the Society's complicity in the Munitions Act and dilution. The Johnstone plant was outside the Glasgow District of the ASE, making life even more difficult for local and national officials.

It was this situation which met greeted new Dilution Commissioners, led by Lynden Macassey, when they were appointed to implement dilution in January 1916. The course which Macassey adopted was to deal directly with the workers at individual plants such as Langs. He made progress at the firm by reaching an agreement on wage rates under dilution before tackling the explosive issue of skilled work, and by proposing Joint Shop Committees made up of managers and workers he outmanoeuvered the "socialistic element" in the union. ${ }^{44}$ The formula provided for the payment of labour in

${ }^{41}$ Ibid., pp. 9-10 for Paterson and North West Employers' Association; Weir in his "Criticism" at MUN $573 / 324 / 15 / 4$, pp. 5, 10, suggested that Government consultation with labour was at the root of the unrest and the Munitions Act should be abolished with direct rule of industry by the state.

${ }^{42}$ Minutes of the proceedings of A.S.E. deputation to the Prime Minister and Mr Lloyd George, 31-12-1915, Mun 5, 70/324/3, pp. 4, 11, and passim.

${ }^{43}$ Ibid., pp. 10-13. 
accordance with the level of skill required for the work, which led inexorably to the conclusion that the rougher work performed by untrained dilutees should be rewarded at non-skilled rates under the "L Circulars". It was not until late February 1916 that trouble recurred at Johnstone as the Lang discovered that they had opened a door to full scale dilution at low rates of pay. Women scraping the beds of machine tools being produced at the plants were engaged on work that was previously undertaken by a tradesman even if it was at the low end of his repertoire of skills. ${ }^{45}$ The policy of the ASE leadership was to use the Lang case to argue for strong guarantees on workshop practice. All work previously undertaken by skilled workers must be fully rated, for to allow the sub-division of craft work would mean "that the engineering trade will disappear entirely". ${ }^{46}$ If the trade rates followed the work, even when it was divided into basic tasks, then the employers would have no financial incentive to replace craftsmen during and after the war. This principle was reinforced by arguments for statutory wage controls and local consultation over dilution schemes at district level.

How does this struggle compare with the conflicts on the Clyde where the members of the Clyde Workers' Committee were involved? Hinton and others have contrasted the kind of craft conservatism found at Langs with the radical proposals of the Clyde stewards. It is argued that these proposals posed a real threat to the authority of the state as well as to the conciliatory policies of unions officials. Marxists since William Gallacher (the Chairman of the (WC) have argued that the unity of the Committee was fatally weakened by the opportunism of David Kirkwood and his Parkhead stewards, who "broke the front" by signing a separate agreement with the Beardmore management. ${ }^{47}$ This breach in the Committee allowed, it is argued, the enemies of the shop stewards to defeat and crush the radicals in the notorious deportations of April 1916. Revisionist historians have usually accepted the revolutionary credentials of the radicals, whilst arguing that the revolutionary syndicalism of the CWC leadership isolated them from mainstream opinion amongst the craftsmen. This explains the rapid collapse of the unrest in spring 1916.

The first point to make about the CWC was that it was a fluid, informal and often erratic body, which was made up of shop stewards and activists

44 L. Macassey, "Memorandum on the Progress of the [Dilution] Commission", 5-21916, pp. 9-11, MUN 5 73/324/15/6; in his Labour Policy - False and True Thornton Butterworth (1922), pp. 78-80, Macassey argued that the Clyde resistance to dilution was calculated to uphold the production of howitzers and barges. Yards and workshops producing these were brought out by the SLP activists.

45 "Minutes of a Conference on Dilution between the Ministry and the A.S.E.", 24-21916, MUN 5 70/324/6, pp. 4-7.

${ }^{46}$ Ibid., p. 10, for Button.

${ }^{47}$ Gallacher, Revolt on the Clyde, pp. 106-107; Hinton, First Shop Steward's Movement, pp. 149-159. 
from a range of shops and occupations. The Committee's origins seem to lie in the original unofficial strike committee of the February 1915 campaign. The body was resurrected in the midst of the autumn unrest over the Munitions Act ${ }^{48}$ In this sense it was a product of the general controversy over the legislation which swept the Clyde area, including the widespread distrust of union leaders who had been consulted when the Government drafted the measure. The amorphous character of the Committee was described by one of its members: ${ }^{49}$

The Clyde Workers' Committee was a heterogeneous crowd which had practically no constitution. It was more a collection of angry Trade Unionists than anything else, which had sprung into existence because of the trouble which was going on on the Clyde. The Clyde Workers' Committee was the result of that trouble.

The debate over dilution gave the CWC an opportunity to challenge the ASE District Committee and in particular the moderate views of Bunton and Brodie. Soon the CWC appealed to shop stewards to report on grievances - an usurpation of power which local and national union officials bitterly resented. ${ }^{50}$

In early January the CWC's newspaper, The Worker put a general argument for workers' control on the Clyde, though the appeal for nationalisation of munitions production was hardly a practicable policy for local stewards to pursue. It was not until the middle of February that the CWC secretary, J. M. Messer, sent the Dilution Commissioners a formal request to discuss a general scheme of dilution which would cover the twenty-nine shops the Committee claimed to represent. ${ }^{51}$ This was almost three weeks after a dilution agreement had come into effect at Parkhead and a month before a dispute at the Beardmore works escalated into a strike. Since Messer was also an ASE steward at Beardmores and was deported with Kirkwood in the crisis, it is difficult to believe that the Parkhead Convenor broke with a united CWC in signing a plant agreement. It seems more likely that the apparent success of the Parkhead scheme encouraged a number of other agreements, including an important agreement at the Barr and Stroud works which employed Muir. ${ }^{52}$ The real intention of the CWC seems

48 Labour Party Report, p. 12.

${ }^{49}$ Ibid., pp. 12-13. The speaker was a CWC member from the British Diesel plant in Springburn.

${ }_{50}$ Ibid., p. 16.

${ }^{51}$ Ibid., "Prepare for Action", The Worker, 8-1-1916. Gallacher opened the first edition with a critical attack on Kirkwood.

52 Labour Party Report, Appendix 4, p. 63 for Barr and Stroud scheme; Gallacher, Revolt on the Clyde, pp. 113-121 for his acknowledgement of progress on dilution. 
to have been to consolidate their position by extending these principles to district level. Therefore the suggestion that Kirkwood's actions sabotaged the initiative of the CWC appears to be unfounded. It was the determination of the Dilution Commissioners not to deal with the Committee at any cost which proved the major obstacle to progress.

There may be a stronger case against Kirkwood for signing a flawed agreement which failed to protect the skilled workers against exploitation and isolated the shop stewards from their union. Two features of the Parkhead agreement provoked controversy. Firstly, the shop stewards conceded that the principle of fair distribution of wages should be paramount, rather than insisting on a strict regard for the integrity of skilled work. This provision was intended to avoid an absurd situation where dilutees on simple operations might earn the same (or more) wages than jig setters and finishers, if all workers would be paid the full trade rate for work that had been executed in the past by tradesmen. ${ }^{53}$ Such a concession weakened the official ASE view, stated and restated in the discussions of the Lang case at national level, that all trade work must receive the district rate. Kirkwood hoped to avoid any such abuse of dilution by a second principle in the scheme: namely, that there should be a formal record of all changes in workshop practice and that the shop stewards should have the right to monitor such changes. This claim of a "power to see" was to provide the breaking point for the whole agreement.

To understand the crisis which erupted at the Parkhead works in March 1916 , we have to remember that union recognition was a recent development at Beardmores. The ASE had been pressing for a union agreement for many years but it was only conceded after the outbreak of the war. By the beginning of 1916 Parkhead had emerged as a massive constituency for the union, with sixty shop stewards under Kirkwood as Convenor. The rapid drafting of the dilution agreement was partly due to Kirkwood's personal relationship with two men: John Wheatley of the Independent Labour Party (ILP), and William Beardmore himself. Kirkwood clearly believed that this agreement gave him, as ASE Convenor, full access to all departments, including female dilutees introduced in the howitzer shop at the beginning of March 1916. After complaints from the Welfare Superintendant and a forewoman, the management abruptly warned Kirkwood and his stewards that any "interference" would lead to dismissal. ${ }^{54}$ After further friction over working hours the shop stewards struck work in mid-March. As other shops began to come out in support of Parkhead in

53 The scheme was discussed in detail at the February 1916 conference at the Ministry, MUN 5 70/324/6, pp. 21-22; Kirkwoord, My Life of Revolt, for his account of Wheatley's hand in the scheme.

${ }^{54}$ Labour Party Report, pp. 21-22. 
late March, the Dilution Commissioners consulted their London masters and at the beginning of April ordered the military authorities to deport the leading stewards at Beardmores and Weirs.

It is difficult to explain the provocative actions of the Beardmore management except as a demonstration of the employer's right to manage the workforce. In a decision that could only be useful as a symbolic affirmation of management power, Kirkwood was told that he could not pass through a gate that connected his own workroom with the neighbouring howitzer shop. When he was later asked about his treatment of Kirkwood, Beardmore struggled to express his deep instinct that the prerogatives of the employer could not be diluted, however much the skills of his workmen might be affected. The threat posed by the spectacle of a free-moving worker had to be dealt with in a decisive way: ${ }^{55}$

the Firm could not possibly manage the place otherwise and that discipline must be maintained in the management of the shops and that it was tantamount to doing away entirely with discipline if such things were to be permitted.

This defence of "law, order and discipline in the management of the shops", was in fact an assertion of the legal power to manage and to subordinate all workers regardless of personal authority or dilution agreements. The final turn of the screw came with Beardmore's threat to prosecute the stewards under the Munitions Act should they resort to a strike. This brought back the memories of the 1915 unrest and provided the immediate background to the decision to strike. ${ }^{56}$

Faced with the determination of the Beardmore management to assert itself against the stewards, the Dilution Commissioners simply let the strike unfold. When it threatened to become widespread they called in military support on the side of the employers. The military authorities in turn were anxious to deport the shop stewards without trial to protect the production of munitions. When reviewing the claims of Colonel Levita to strict impartiality in the termination of the dispute, a Labour Party enquiry into the deportations wryly noted, "on this line of reasoning the Competent Military Authority might as well have arrested Sir William Beardmore, Admiral Adair and Mr Chisholm as Mr Kirkwood [ . . .]". ${ }^{57}$ It was natural to think of workers rather than managers as disrupting production and to uphold the rightful authority of the employer.

The shop stewards were also abandoned by their own officials and refused even union benefit on deportation. The actions of the ASE exec-

55 Ibid., Beardmore quoted p. 24.

${ }^{56}$ Ibid., pp. 33-34, 37-38.

57 Ibid., p. 42. 
utive have to be seen in context. They were committed to establishing a national agreement which would include statutory guarantees on wage rates and preferential treatment for skilled workers. This would extend the pre-war strategy of working through procedures to secure the position of the ASE as the voice of the whole engineering industry. Struggles between the shop stewards and the District Committee in Glasgow only threatened the union with internal damage. The Clydeside workforce was deeply suspicious of legislative controls since the Munitions Act, but the ASE executive was committed to working with the state for a dilution programme. Individual agreements reached at Parkhead and other plants were disowned by the executive, who recognised the danger to the unity of the union and the challenge to their own authority. The strength of the shop stewards' case was their bid for a share in decisions over plant dilution. Their weakness was in the limited leverage they could bring to bear on employers and the state once the firm declared its sole right to manage. The executive had more influence with central government but based their case on a formal recognition of craft customs and procedures. The crushing of the Parkhead stewards did not mean the collapse of union power but it did mean the end of an attempt to create a politics of skill that would extend union influence into the formal province of workshop management.

Historians continue to differ about the viability of the shop stewards' political enterprise and the importance of the engineering case. Reid argues that the massive shipbuilding sector displayed a very different pattern of intervention and conflict during the war years. His research suggests that the shipyard workers were able to resist the introduction of unskilled female labour without pursuing the "rank-and-filist" strategies of the engineering stewards. The success of official union policy in limiting dilution and securing reform of the Munitions legislation, confirmed the position of the conservative craft societies. Far from betraying their members the shipbuilding unions proved the strength of organised labour during the war. ${ }^{58}$ In this light the dilution and deportation crisis of early 1916 appears as marginal to the mainstream labour movement in Glasgow. The war years marked the success of official unionism and the triumph of craft sectionalism on the Clyde.

The evidence shows that Lynden Macassey's optimistic forecast of early 1916 , that "very substantial schemes of dilution will be arranged in the Clyde Shipyards" proved a miscalculation..$^{59}$ By the end of the year he was bemoaning the lack of progress made in the shipbuilding sector and the fact

${ }^{58}$ Reid, "Dilution, Trade Unionism and the State", p. 65, 69-70.

${ }^{59}$ L. Macassey, "Dilution of Labour in the Clyde District", 29-2-1916, MUN 5 $73 / 324 / 15 / 9$. 
that "little or no attempt is being made to introduce [dilution] into Shipbuilding and Shiprepairing Yards". ${ }^{60}$ There had been progress in diluting engineering and electrical work at major Clyde yards, but there had been a sorry lack of urgency in reforming shipyard practices. ${ }^{61}$ It does not follow that the slow progress in dilution should be seen simply as a triumph for craft traditionalism. There were at least four obstacles to the progress of shipyard dilution. Firstly, the physical character of shipyard work meant that increased output would be secured by improving the flexibility of skilled workers rather than introducing female labour to heavy tasks. ${ }^{62}$ Secondly, the nature of contracting work on cost-plus terms removed the incentive to economise on labour, shed workers or provoke stoppages. ${ }^{63}$ Thirdly, the unions insisted on trade prerogatives and union discipline remaining in return for limited cooperation on power tools ${ }^{64}$ Finally, and most importantly, the division of responsibility within government itself served to prevent the imposition of a determined manpower policy by the Ministry of Munitions. Macassey argued for a personal commission to secure dilution by direct agreements with the District Committees in the shipbuilding areas, breaking the Admiralty's grip on the shipyards and averting the unrest provoked by the Munitions Act. ${ }^{65}$

After their bitter experience of the Munitions Act in 1915, the shipyard workers were determined to defend their primitive autonomy inside the yards. The shipbuilding trades did not form a common front to attack their own officials, as did engineering stewards, but there were similar frictions during and after the great Munitions Act unrest of 1915. The Amendment Act of early 1916 did not satisfy them completely. In fact, a major reason for the introduction of the new legislation was to enable the state to classify private merchant construction as essential war work and so place the workers under official control. ${ }^{66}$ Amongst the unions the leaving certificates

${ }^{60} \mathrm{~L}$. Macassey, "Report on the present serious unorganised condition of shipyard labour", 14-12-1916, p. 12, MUN 5 57/320/36. Once again Macassey stressed his own invaluable contributions to progress.

${ }^{61}$ Macassey, "Dilution of Labour", MUN 5 73/324/15/9, gives details of "Schemes accepted and proposed. .." as appendices.

${ }^{62}$ Macassey, "Report on the condition of shipyard labour", MUN $557 / 320 / 36$, pp. 11-12.

${ }_{63}^{63}$ Ibid., pp. 13-14.

${ }^{64}$ Ibid., p. 9; cf. Reid, "Dilution, Trade Unionism and the State", for an emphasis on this factor.

${ }^{65}$ Macassey, "Report on the condition of shipyard labour", p. 16, where he advocates a "clearly defined and forcibly applied Government policy".

66 "Notes for Ministry on introduction of Munitions Amendment Bill to House of Lords", Mun $520 / 221.1 / 40$, identified the main object of the Bill to "extend and amend the Munitions of War Act without affecting its main principles". Some changes in the form of the leaving certificate was conceded but Section 7 of the Act was defended as "a very necessary provision". Most of advice concerned the extension of the Act to the 
remained a major grievance and explains the intransigence of both engineering and shipbuilding trades to the extension of dilution in 1917, as the loss of mercantile marine forced the Government to reconsider dilution proposals. ${ }^{67}$ Unions in the shipyards as well as engineering were seeking a guarantee that the state would honour its promise to restore working practices after the war. It is significant that the Government was unable to win their confidence in 1916-1917, as both shipbuilding and engineering unions refused further concessions. ${ }^{68}$ Prominent amongst the opponents of conciliation was the ASE, refusing to cooperate in an Advisory Committee to extend dilution in the shipyards. ${ }^{69}$

Official records show that female dilution was not, and could not, be introduced on the same scale in an industry where the physical conditions of work and the diversity of skills demanded experienced labour. The division of work was largely directed to the production of complex and specialist vessels. Yet there were intense conflicts within the shipyard unions during labour unrest. As Sharp of the Boilermakers told the Balfour-Macassey enquiry (which investigated Clyde unrest in 1915), all the officials around the table "are under suspicion. We are criticised from one end of the Clyde to the other. ..". ${ }^{70}$ The Boilermakers and other societies used the Shipbuilding Trades Agreement to sustain the influence of the local "vigilance committees" on the Clyde, defending the autonomy of the trades and the informal discipline procedures which maintained the status quo before the Munitions Tribunals were set up. ${ }^{71}$ Given the opposition of the Admiralty to the Dilution Commissioners and the support of engineering unions in the fight against further dilution on the Clyde, it is important not to exaggerate the independent achievement of shipyard unionists.

In this light the contrast drawn by Reid between engineering and shipbuilding appears to be exaggerated. In both sectors the active members and their officials were striving to secure agreements to defend their trade and give them some direct control over the labour market. The shipyard unionists had allies of convenience in the British Admiralty, which enabled them to resist the Dilution Commissioners with success. The ASE had less room for manoeuvre given the proven need for repetition work on shells and

"Construction of merchant ships" where specified as essential war materials.

67 "Conference proceedings between the Ministry of Munitions and the Engineering and Shipbuilding Industries", 13-8-1917, pp. 5-7, 15-21, MUN 5 71/324/30, for certificates and conscription; cf. Reid, "Dilution, Trade Unionism and the State", p. 65, for suggestion that the 1916 Amendment Act had "removed all the causes of grievance which Clyde workers and union officials had raised over Section $7[\ldots]$ ".

68 "Conference proceedings", pp. 27-28, Boilermakers' Society.

${ }^{69}$ Ibid., pp. 40-43, 47-50. The A.S.E. was again concerned with the recognition of its premier status.

${ }_{70}$ Balfour-Macassey Enquiry Minutes, p. 558.

71 Ibid., pp. 510-513 and passim. 
guns, but they also were seeking a secure agreement with the Government that would recognise their customary practices. The shipyards reached agreements on naval and mercantile production in 1916-1918, though the unions had more "defensible space" in dealing with the employers. The survival of primitive autonomy meant that the shipbuilding unions were not torn by debates over union strategies for the control of work. There were also shared campaigns against legislation and state controls which helped to reduce barriers between trades as the unions tried to devise a method of coordinated bargaining in their dealings with employers and the state itself. Even more important for an understanding of subsequent political change were the combined struggles on the ground in areas such as Govan and Shettleston, where the conflicts of 1915 were followed by struggles over trade exemptions (from military service) and the battle against "industrial conscription".

\section{The politics of the Clyde}

Much of the debate on Clydeside industry turns on the political implications of these workplace struggles. From Marxist and revisionist accounts we receive different images of the British state and workers' attitudes to government policies. Some writers argue that the result of wartime unrest was to push the state into pro-labour reforms, which gave the labour movement a working model of the socialist state and laid the foundations of Labour's success after $1918 .{ }^{72}$ This view raises profound questions about the wartime reforms and the perceptions of organised labour. There is no space here to discuss the complex workings of the state and its reconstruction in the war years. ${ }^{73}$ Whether we see the wartime state as a repressive agent of industrial capitalism or as the sponsor of organised labour, there remains the question why west Scotland should have seen such a decisive shift in support for socialist candidates after 1918. In particular, we need to assess the contribution of workplace conflicts to the rise of socialist politics on the Clyde.

Recent research indicates that earlier Marxist studies have tended to exaggerate the importance of syndicalist and socialist sects whilst neglecting the activities of such bodies as the Independent Labour Party and the Labour Party itself. ${ }^{74}$ By the later years of the war the ILP saw an extraordinary surge of membership in west Scotland. This was accompanied by

72 Reid, "Dilution, Trade Unionism and the State", pp. 65-70; Rubin, War, Law and Labour, pp. 204-209 for a "corporatist" variation of the argument.

${ }^{73}$ R. Lowe, Adjusting to Democracy: The role of the Ministry of Labour in British Politics, 1916-1939 (Oxford, 1986), pp. 14-75 and passim provides an excellent counterpoint to K. Middlemass, Politics in Industrial Society (London, 1979).

${ }_{74}$ J. Smith, "Labour Tradition in Glasgow and Liverpool", and her doctoral thesis, 
strong support for ILP candidates in the elections of 1918-1924. Such a transformation of Labour politics in the war years should not be explained simply, or even primarily, in terms of shop-floor campaigns by skilled workers. Important areas of activity which contributed to the building of Labour support during the war years included the housing and rents campaigns, the movements to defend civil liberties and oppose conscription, and the demand for substantial reconstruction of society after the war. The affect of these campaigns was to radicalise existing bodies and to introduce new kinds of organisation into politics. ${ }^{75}$

These campaigns were often successful because they directed workplace resistance to the wider campaigns on such issues as rents. The peculiar character of trade unionism in west Scotland, with its late and rapid growth in the face of employers' hostility, also coloured Scottish Labour politics. The formative years of union growth corresponded with the rise of the ILP, influencing activists on the trades councils and local branches of the skilled unions. Trade-union officials took part in such bodies as the Scottish Advisory Council, but it was ILP activists such as James Maxton and John S. Taylor who dominated proceedings. ${ }^{76}$ Labour Party leaders such as Henderson found themselves denounced by Scottish union activists and tried to rein in the rebellious northern members. It proved extremely difficult to bring the brilliant ILPers under the control of union officials or the London executive of the Labour Party. ${ }^{77}$ One reason for the political success of ASE activists such as Taylor and Harry Hopkins, was their leading role in Munitions Act unrest and the fight against the Military Service Bill of $1916 .^{78}$

Frictions between the Party executive and the Scottish activists came to a head in 1917-1918. Henderson and his allies in London told the Scots to concentrate their efforts on the new constitution for the whole Party and on

"Commonsense Thought and Working Class Consciousness: Some Aspects of the Glasgow and Liverpool Labour Movements in the Early Years of the Twentieth Century" (Edinburgh, 1980), provides a corrective.

${ }^{75}$ J. Melling, "Work, Culture and Politics on Red Clydeside: the ILP during the First World War", in A. McKinlay and R. Morris (eds), The ILP in Scottish Politics (Manchester, 1990).

${ }^{76}$ Labour Party Archives, [National] Executive Committee Minutes, 14-4-1915-24-61915, 30-7-1915 - 16-9-1915 [hereafter, EC Mins].

7 Ibid., 17-3-1916 - 19-10-1916; also the ILP Council's circular of 18-12-1917 at 8-10-1918.

${ }^{78}$ Ibid., 19-10-1916-2-11-1916; in spring 1916 the Govan L.R.C. had selected William Sharp as their candidate for a proposed bye-election contest, 29-3-1916 - 19-4-1916, 21-8-1916. The withdrawal of Sharp later in the war suggests that his conversion to Labour was early and of a particular quality, not the result of mature wartime experience. Ibid. , 6-1-1916 - 12-1-1916, 7-12-1916 - 18-4-1917; "Munitions of War Amendment Bill: Notes on Clauses", MUN 5 20/221.1/40, for comments of civil servants Llewellyn Smith, Beveridge, Wolff and Miles on the proposals of Labour. 
preparations for elections in 1918. The Scottish leaders were more interested in gaining autonomy for Party members in Scotland and in building support amongst industrial workers. ${ }^{79}$ ILPers dominated the selections lists of Labour candidates for Parliament, though their conception of political work was different from that of the Labour leaders. As the latter noted: ${ }^{80}$

While on the industrial and propaganda side of the movement there has been considerable activity in Scotland, there has been a lack of concentration upon effective political organisation.

It may have been more accurate to have stressed the diversity and fluidity of socialist politics in Scotland at this period. This helps to explain the tension between the London executive and local activists when prominent Marxists such as John Maclean were selected as Labour Candidates and the Scottish party urged its executive to adopt a full programme of political and social reforms by Labour. ${ }^{81}$

The open "movement politics" of Scottish Labour had its origins in the pre-war work of the ILP and the practical experience of wartime struggles. An important feature of the rent strikes of 1915 had been the convergence of campaigns which demanded the repeal of the Munitions Act and the control of rents. This convergence of demands was not the result of a spontaneous class consciousness on the Clyde. Nor were the struggles orchestrated by a revolutionary party. The greatest contribution was made by the network of activists who assembled in the Scottish ILP. Skilled workers and feminists as well as small businessmen figured in this network. It was their practical and organising genius which largely explains the size and success of wartime campaigns. Even more important than the scale of Scottish movements was the style of socialist politics. Despite the vigorous polemics of John Maclean, there was a noticeable decline of sectarianism in the war years.

The campaigns in west Scotland steadily influenced the wider world of Labour politics. By 1917 the Clyde shop stewards had their case investigated by the Labour Party and Henderson was again forced to justify his participation in Government. ${ }^{82}$ The Labour Party was ultimately to benefit in Scottish elections by the upheaval of socialist activity, though the boundaries of socialist politics were to remain fluid and unfixed until 1920. At this

79 Ibid., 9-12-1915; 1-1918, 9-5-1918, 27-8-1918. S.A.C. Minutes of 4-12-1917 at EC Mins, 13-12-1917.

${ }^{80}$ Ibid., 31-8-1918.

81 Ibid., 31-7-1918, for discussions at the Policy and Programme Committee of the Party; 29-6-1916, for agreement to affiliate the British Socialist Party to the Labour Party.

${ }^{82}$ Labour Party Report, pp. 5, 49. 
point the structures of party politics hardened as Labour turned to electoral power and the new Communist Party tried to rekindle direct action on the shop floor and the streets of Clydeside ${ }^{83}$ Many Labour activists returned to the scenes of their wartime campaigns to stand in elections after 1918. As the lines of party division hardened, Labour moved away from issues of industrial authority and social power towards a constitutional agenda. The trade unions quickly reasserted their sectional interests and faced a series of bitter defeats at the hands of the Clyde employers in the early 1920s. Sweeping victories in west Scotland during the elections of 1924 helped to bring Labour to power, but by then the context for socialist politics had changed dramatically.

\section{Clydeside and the politics of skill: conclusions}

The contribution of organised labour to the making of socialist politics remains a subject of vigorous debate. Marxist studies of British politics have usually portrayed Labour politics as the triumph of a sterile "Labourism", grounded in the defensive attitudes of Victorian trade unionism when a labour aristocracy of skilled workers formed privileged societies. ${ }^{84}$ For Hinton it was the advance of technology and dilution which threatened the position of the skilled workers during the war, driving a majority into defensive craftism and radicalising a minority of shop stewards. They were eventually crushed beneath the weight of craft prejudice, union bureaucracy and the capitalist state, but they formed the core of Communist Party activists in the $1920 \mathrm{~s} .{ }^{85}$ This interpretation of socialist politics is firmly rejected by historians such as McLean and Reid, who insist on the integrity of craft-union policies and their defence of the sectional interests of their members. The popular constituency for socialism is located in such factors as housing, religion and the positive perception of state controls. ${ }^{86}$ Whilst McLean argues that the destructive militancy of Glasgow workers inhibited the rise of responsible Labour politics, Reid suggests that the wartime state convinced such workers of the viability of state socialism.

Whilst the debate has focussed attention on the role of skilled workers in changing politics of west Scotland, it has also obscured the complex strug-

${ }^{83}$ McKibbin, The Evolution of the Labour Party; I.G.C. Hutchison, A Political History of Scotland, 1832-1924 (Edinburgh, 1986), pp. 256-265 and passim gives a detailed background; A. McKinlay's essay in McKinlay and Morris (eds), The ILP in Scottish Politics, for an excellent account.

${ }^{84}$ See note 5 on page 4 for references.

${ }^{85}$ Hinton, First Shop Stewards' Movement, and J. Hinton and R. Hyman, Trade Unions and Revolution: the Industrial Politics of the Early British Communist Party (London, 1975).

${ }^{86}$ McLean, The Legend of Red Clydeside, pp. 161-183; Reid, "Dilution, Trade Unionism and the State", pp. 69-70. 
gles for power and authority in that industrial society. Both Marxist and revisionist accounts tend to present "politics" as a formal activity outside the production process. Unions are portrayed as institutions which express the particular interests of the workforce. In fact, there was a necessary politics implicit in the relations of production. The preservation of skill clearly depended on collective action as well as the physical conditions of work. Craftsmanship involves not only the performance of manual tasks but a dual relationship to the institutions of capitalist production and the craft fraternity. Before the war these relations were buried beneath voluntary bargaining and the customary practices of British industry. Craftsmen continued to enjoy a significant degree of discretion over the preparation and completion of their work. The crude arrangement of production and the range of specialised tasks in the shipyards gave the waterfront trades a greater, if primitive, autonomy in bargaining over work and wages. Engineering workers saw their freedom of movement contract in the pre-war years as management reforms were introduced.

These changes provide a context for understanding the policies of the unions. There was a subtle, but significant, difference in the relationship between workshop practice and formal procedures in the two industries. Local employers tried to tighten their control of labour in each sector before 1914. Engineering firms were the more successful in pressing reforms on the workforce. The shipyard societies were more effective in manipulating the primitive autonomy of the workplace to defend their members against tighter supervision. The response of unions in both sectors to the challenge of reform was to strengthen their position by a drive for total membership of the union. Local vigilance committees were appointed to guard the frontier of control and check the credentials of tradesmen. Although unions in the two sectors pursued similar strategies, the shipyard societies were in a stronger position. In the face of the employers' failure to impose discharge notes on the Clyde, the shipyard unions offered the firms a local agreement to ensure the supply of qualified tradesmen. The primitive autonomy of the yards strengthened the hand of the union officials. In the engineering workshops, the ASE faced a challenge from semi-skilled labour which could not be ignored. The response of the union was to accept the logic of centralised bargaining and conciliation procedures with the employers. At the same time there was a strong membership drive in areas such as Glasgow, with shop stewards appointed to recruit members and report on local conditions. These policies placed a strain on the ASE before 1914 , as districts resisted executive authority, though national agreements still held on the outbreak of war.

Wartime demand destroyed this fragile detente by changing the whole basis of industrial bargaining in the munitions districts. Craftsmen found their initial bargaining strength removed and their skills jeopardised by 
a series of state policies in 1915-1916. The clear propensity of the state to underwrite the authority of management and impose conditions (and wages) on the workplace served to openly politicise issues of workplace bargaining. The degree to which the authority relations of industry were also politicised can be traced in the disputes provoked by the "legal" actions of foremen. Union officials failed to protect their members against the aggression of the employers during the Munitions controversy and a crisis of confidence spread throughout the Clyde area. Different sections of the membership seized the opportunity to devise their own agreements. Despite the fierce criticism of the Parkhead stewards by left-wingers such as Gallacher, even the CWC was, in practice, seeking to secure the position of the skilled trades by shifting the basis of control from the craft society to the shop committee. This view challenges the argument that the real significance of the dilution struggle lay in the polarisation of the tradesmen and a struggle between the militant shop stewards and union officials. Nor can the unions be seen simply as cathedrals of craftism. The Lang tradesmen were trying to defend their autonomy in the face of female dilution, as were the Parkhead stewards ${ }^{87}$ The frictions with the full-time officials arose from the anxiety of the ASE executive to secure a binding national agreement and destroy the challenge of the CWC to the District Committee. This challenge was a "political" threat to the fixed procedures of the union, but grew out of the practical experience of shop stewards rather than the political doctrines of local syndicalists.

The deportation crisis revealed the complex tensions which had built up by spring 1916. The Parkhead management clearly felt the need to assert their management prerogatives on the shop floor, even though they could not justify their behaviour in rational terms. Their customary and moral authority was slipping away as Kirkwood dealt with both practical problems and disputes. Once the management had made their move, the Parkhead stewards found themselves isolated. The Dilution Commissioners did not intervene until the strike was well under way. The local and national ASE officials left their members to fight without union benefits, and even the CWC (under Gallacher) refused to support the struggle. Having made their own agreement the tradesmen were left to fight alone, though a large number of workers at Weirs and other shops came out in support.

Perhaps the main political lesson which the union activists learned from the deportations of early 1916, was that the state could not be regarded as neutral when essential production - such as munitions - was threatened. Faced with a choice between the authority of management and proposals which threatened the dilution of management authority, the Government was ready to use military force to assert the prerogatives of management

${ }^{87}$ J.W. Muir, The Worker 1, 8-1-1916, gives the radicals' view. 
and of the state itself. The price that the Government paid was a bitter suspicion of the Ministry and a determined opposition to any move which might bring a conscription of industrial labour. Having seen their customary defences undermined by official control, craftsmen were unimpressed with the patronage of politicians and - as one official told the Ministry looked on consultation as "a means of chloroforming them". ${ }^{88}$ Even the national officials tired of the endless advisory committees set up to pacify union opinion. ${ }^{89}$

The political consequences of the industrial unrest were not immediately apparent. Many of the leading figures eventually found their way to the Communist Party, but numerous others remained in the ILP and the Labour Party. We cannot draw a straight line between the workplace struggles and the wider politics of Scottish Labour. Campaigns on rents and housing also played a key part in the success of Labour politics. But these were not discrete areas of activity, separate from the confrontations between skilled workers and the wartime state. The same network of activists and organisers who figured in the Munitions unrest and the rent strikes also took part in the dilution campaigns and the fight against industrial conscription. It was the ILP which drew on these experiences of conflict and won the support of trade unionists in the Scottish Council of the Labour Party. The ILP's success in attracting the Glasgow unions to an open, movement politics explains the rise of such dedicated activists as Harry Hopkins to leadership of the ASE's District Committee by 1919.

Such Labour activists tended to see politics as the expression of "the whole Glasgow Movement", rather than the disciplined activities of a single party. ${ }^{90}$ For these campaigners, the challenges to the authority of the employers and the responses of the state had demonstrated the need for a politics that could provide a strategy for the wider labour movement. The skilled workers moved from the narrow world of the craft society to this industrial and political movement. They were helped by the open, fluid style of political campaigning adopted by socialists in the later years of war. Doctrinal and organisational barriers were to be raised in the early $1920 \mathrm{~s}$, against a background of industrial defeat and party rivalries. By that time the ILP had secured the hold of Labour over the industrial districts of west Scotland.

88 "Conference of the engineering and shipbuilding industries", 13-8-1917, MUN 5 $71 / 324 / 30$, p. 21.

${ }^{89}$ Ibid., p. 47.

${ }^{90}$ EC Mins, 2-11-1916. 